\title{
EXCESSIVE DAYTIME SLEEPINESS IN CAMPO GRANDE GENERAL POPULATION, BRAZIL
}

\author{
José Carlos Souza', Luiz Alberto Magna², Rubens Reimão³
}

\begin{abstract}
The prevalence of excessive daytime sleepiness (EDS) in general population was determined by means of 408 home interviews of adults, in a representative sample of Campo Grande city, Brazil. The random sample was stratified by sex, age and economic social status. EDS was considered in those with indexes 11 or more in the Epworth Sleepiness Scale. Statistics used chi-square, Fisher and Pearson tests; and inferences based on binomial distribution parameters; the significance level was $5 \%$ and confidence interval $(\mathrm{Cl})$ was $95 \%$. The prevalence of EDS was $18.9 \%$ of the general population ( $\mathrm{SD}=1.9 \% ; \mathrm{Cl} 15.1 \%$ to $22.7 \%$ ). No significant association was found between EDS and the use of hypnotics, nor with insomnia, body mass index, sex, age, years of schooling, economic social status, marital status, occupation and the use of alternative means to improve sleep. When the sample was separated according to sex, only the male group showed significant association between EDS and actual insomnia $(p=0.005)$.
\end{abstract}

KEY WORDS: sleepiness, sleep, sleep disorders, Epworth Sleepiness Scale.

\begin{abstract}
Sonolência diurna excessiva na população geral de Campo Grande, MS
RESUMO - Buscou-se a prevalência da sonolência diurna excessiva (SDE) com 408 entrevistas domiciliares de adultos, em amostra representativa da população geral da cidade de Campo Grande, MS. A amostragem aleatória foi estratificada por sexo, idade e classe social. Tinham SDE as pessoas com 11 ou mais pontos na Escala de Sonolência Epworth. Usaram-se os testes de qui-quadrado, Fisher, Pearson e inferências com base nos parâmetros da distribuição binomial; nível de significância $5 \%$ e intervalo de confiança (IC) 95\%. Tinham SDE $18,9 \%$ da população ( $d p=1,9 \%$; IC $15,1 \%$ a $22,7 \%$ ); não houve associação significativa entre SDE e uso de hipnóticos, nem insônia, índice de massa corporal, sexo, idade, escolaridade, classe sócio-econômica, estado civil, ocupação e uso de meios alternativos para dormir melhor. Ao serem separados de acordo com sexo, apenas no sexo masculino houve associação significativa entre SDE e presença de insônia $(p=0,005)$.
\end{abstract}

PALAVRAS-CHAVE: sonolência, sono, distúrbios do sono, Escala de Sonolência Epworth.

Excessive daytime sleepiness (EDS) is a fairly common complaint in general population surveys ${ }^{1-12}$. The causes of EDS may vary from changes in daily sleep habits to drug abuse or dependence, as well as sleep disorders as sleep apnea syndrome, narcolepsy or depression ${ }^{13-17}$. The health consequences of EDS include automobile accidents, reduced performance at work and school, and quality of life impairment ${ }^{7,13,18-23}$.

The purpose of this research is to evaluate the prevalence of EDS in the Campo Grande city general population, and correlate it with independent variables. This research is part of a larger project we are carrying on to evaluate sleep habits and sleep disorders in this city.

\section{METHOD}

Campo Grande is the capital city of Mato Grosso do Sul State. It is located in Brazil central-west region. The population is estimated (year 2001) in 662534 inhabitants.

Home interviews were performed from April $3^{\text {rd }}$ to $8^{\text {th }}$, 2001. Interviews included 408 inhabitants, 18 years or older, from the seven urban regions of Campo Grande city. The sample was obtained at random, by the cluster method; and stratified by sex and age (according to Instituto Brasileiro de Geografia e Estatística, 1996) ${ }^{24}$; and stratified by economic social status based on Brazilian Market Research Association. A pilot study was done initially with 30 persons, in order to adjust the Epworth Sleepiness Scale (ESS) ${ }^{25}$ to the local characteristics and the staff of field research with this questionnaire.

Campinas State University, Campinas SP, Brazil (UNICAMP), and the Clinical Neurology Division, Hospital das Clínicas, University of São Paulo Medical School, São Paulo, SP, Brasil (FMUSP): ${ }^{1}$ Psychiatrist, Professor, Dom Bosco Catholic University, and Mental Health PostGraduate Course, UNICAMP; ${ }^{2}$ Head, Medical Genetics Department, UNICAMP; ${ }^{3}$ Assistant, M.D., Ph.D., Hospital das Clinicas, FMUSP. This research was partially funded by Dom Bosco Catholic University, Campo Grande MS, Brasil, and Produtos Roche Químicos e Farmacêuticos S/A, São Paulo, SP, Brazil.

Received 2 January 2002, received in final form 4 March 2002. Accepted 14 March 2002.

Dr. Rubens Reimão - Avenida Indianópolis 2784 - 04062-003 São Paulo SP - Brasil. FAX: 1155897422. 
The 408 home personal interviews were carried out by a staff properly trained by the authors, and a consistent application of the questionnaire was obtained. The standardized questionnaire was adapted from Giglio ${ }^{26}$ and the International Classification of Sleep Disorders ${ }^{27}$. The independent variables studied were: sex, age, schooling, economic social status, marital status, employment, presence of insomnia, use of hypnotic drugs, and use of alternative means for better sleep.

To detect EDS the ESS was applied ${ }^{25}$. This is a standard, low-cost, quick and easy to apply scale in large population researches $3,6,25,28$. ESS focuses the various tendencies of excessive sleepiness, with eight questions, encompassing daily monotonous life situations: sitting down and reading; watching TV; sitting down in public places (classroom and church); riding in a train, bus or car for an hour; lying down in the afternoon to rest; sitting down and talking; sitting down after lunch; stopping for minutes in heavy traffic. It distinguishes feeling asleep from just feeling tired. The interviewed must give a mark from zero to three, according to his/her tendency to fall asleep: zero, no chance to fall asleep; 1, low chance; 2, moderate chance; 3, high chance. EDS is considered when the answers to the eight questions sum up to 11 or more. ESS scores had been validated comparing to the gold-standard of EDS, the Multiple Sleep Latency Test ${ }^{25,28}$. ESS does have high internal consistency, measured by the Cronbach alpha index $(0.88)^{1,28}$.

This study was approved by the Research Ethics Committee from Campinas State University. Informed, free and written consent was signed by all participants.

The statistical methods were descriptive, and chi-square test, Fisher exact test, Pearson coefficient correlation, and inferences based on the binomial distribution parameters were used. The significance level utilized was $5 \%$ and the confidence interval (IC) adopted was $95 \%$.

\section{RESULTS}

EDS was present in $18.9 \%$ of the general population studied ( $\mathrm{sd}=1.9 \%$; IC from $15.1 \%$ to $22.7 \%$ ). Table 1 shows the distribution of the whole sample, based on total ESS, and the social demographics, as well as the presence of insomnia, the use of hypnotic drugs, and the use of alternative means for better sleep.

Table 2 shows chi-square test applied to the Table 1 data. None of the independent variables showed significant association with EDS, according to the classification based on total ESS.

The simple correlation analysis between the total ESS and weight, height and body mass index [BMI= weight $(\mathrm{kg}) /$ height $\left(\mathrm{m}^{2}\right)$ ] was non significant, and the Pearson correlation coefficients were, respectively: 0.005 (Degree of Freedom $=402, p=0.9240),-0.014$ $(\mathrm{DF}=373, \mathrm{p}=0.7890)$ and $0.002(\mathrm{DF}=369, \mathrm{p}=0.9650)$.
The analysis of social demographic variables, as well as insomnia, the use of hypnotic drugs and the use of alternative means for better sleep was obtained in each sex (male, female), and related to the total ESS index. The chi-square test was applied to this data and in the male group is shown in Table 3. The only significant association was the presence of insomnia and EDS in the male group $(p=0.0050)$.

The chi-square test was applied to the data in the female group (Table 4). None of the independent variables showed significant association with EDS in the female group.

The simple correlation analysis between the total ESS index and weight, height and BMI, in the male group, was not significant, and the Pearson correlation coefficients were, respectively: $0.037(D F=199$, $\mathrm{p}=0.6000), 0.011(\mathrm{DF}=194, \mathrm{p}=0.8790)$ and 0.024 $(\mathrm{DF}=193, \mathrm{p}=0.7380)$.

The same analysis applied to the female group, showed similar results, and the Pearson correlation coefficients were, respectively: $-0.022(D F=201$, $p=7570),-0,027(D F=177, p=0.7220)$ and -0.016 $(D F=174, p=0,8350)$.

\section{DISCUSSION}

The prevalence of EDS (18.9\%) in our sample is close to most indexes observed in recent general population studies by Janson et al. ${ }^{11}(14.7 \%)$ in Northern European countries; Téllez-López et al. ${ }^{12}$ (21.5\%) in Monterrey city, Mexico; Ohayon et al. ${ }^{16}(20.7 \%)$ in the United Kingdom; $\operatorname{Hara}^{8}(16.8 \%)$ in Bambuí town, Minas Gerais State, Brazil.Lower prevalence of EDS indexes were obtained in other recent general population studies by Martikainen et al. ${ }^{10}(9.8 \%)$ in Finland; Hubblin et al. ${ }^{9}(9.0 \%)$ in Finland; Roberts et al..$^{17}$ (6.7\%) in California, USA. Higher prevalence of EDS index was obtained by Hays et al. ${ }^{22}(25.2 \%)$ in a recent large population $(\mathrm{N}=3,962)$ of $65+$ year olds.

Our findings did not show significant correlations between EDS and sex, age, schooling, economic social status, employment. This is in agreement with other similar large, recent general population studies that widely agree with the lack of correlation between EDS and sex, age, schooling, economic social status, employment $2,12,14,16,22$. We suppose that this lack of correlation may be due to the large variety of EDS causes, summing up in the general population studies.

EDS may be found in numerous disorders, including insomnia, depression, obstructive sleep apnea syndrome, narcolepsy, and the use of hypnotic drugs ${ }^{14,21,29}$.

In our total sample, there was no significant correlation between EDS and insomnia. However, when 
Table 1. Distribution of frequencies and the relative frequencies of Excessive Daytime Sleepiness in relation to the total sample, to sex, age, schooling, economic social status, marital status, employment, presence of insomnia, the use of hypnotic drugs and alternative means for better sleep.

\begin{tabular}{|c|c|c|c|c|c|c|}
\hline & \multicolumn{3}{|c|}{ Epworth index } & \multicolumn{3}{|c|}{ Epworth general percentage (\%) } \\
\hline & without EDS & with EDS & Total & without EDS & with EDS & Total \\
\hline Total & 331 & 77 & 408 & 81.1 & 18.9 & 100.0 \\
\hline \multicolumn{7}{|l|}{ Sex } \\
\hline Male & 170 & 32 & 202 & 41.7 & 7.8 & 49.5 \\
\hline Female & 161 & 45 & 206 & 39.5 & 11.0 & 50.5 \\
\hline \multicolumn{7}{|l|}{ Age years } \\
\hline 18 to 19 & 21 & 4 & 25 & 5.1 & 1.0 & 6.1 \\
\hline 20 to 29 & 96 & 24 & 120 & 23.5 & 5.9 & 29.4 \\
\hline 30 to 39 & 87 & 19 & 106 & 21.3 & 4.7 & 26.0 \\
\hline 40 to 49 & 62 & 11 & 73 & 15.2 & 2.7 & 17.9 \\
\hline 50 to 59 & 28 & 10 & 38 & 6.9 & 2.5 & 9.3 \\
\hline 60 or more & 37 & 9 & 46 & 9.1 & 2.2 & 11.3 \\
\hline \multicolumn{7}{|l|}{ Schooling years } \\
\hline zero -3 & 66 & 18 & 84 & 16.2 & 4.4 & 20.6 \\
\hline $4-8$ & 87 & 16 & 103 & 21.3 & 3.9 & 25.2 \\
\hline $8-10$ & 67 & 16 & 83 & 16.4 & 3.9 & 20.3 \\
\hline $10-12$ & 85 & 17 & 102 & 20.8 & 4.2 & 25.0 \\
\hline 16 or more & 26 & 10 & 36 & 6.4 & 2.5 & 8.8 \\
\hline \multicolumn{7}{|c|}{ Economic social status } \\
\hline A & 26 & 8 & 34 & 6.4 & 2.0 & 8.3 \\
\hline B & 63 & 13 & 76 & 15.4 & 3.2 & 18.6 \\
\hline $\mathrm{C}$ & 114 & 29 & 143 & 27.9 & 7.1 & 35.0 \\
\hline$D / E$ & 128 & 27 & 155 & 31.4 & 6.6 & 38.0 \\
\hline \multicolumn{7}{|l|}{ Marital status } \\
\hline Single & 95 & 24 & 119 & 23.3 & 5.9 & 29.2 \\
\hline Married & 198 & 43 & 241 & 48.5 & 10.5 & 59.1 \\
\hline Divorced & 18 & 5 & 23 & 4.4 & 1.2 & 5.6 \\
\hline Widow & 20 & 5 & 25 & 4.9 & 1.2 & 6.1 \\
\hline \multicolumn{7}{|l|}{ Employment } \\
\hline Stable & 77 & 18 & 95 & 18.9 & 4.4 & 23.3 \\
\hline Unstable & 89 & 15 & 104 & 21.8 & 3.7 & 25.5 \\
\hline Jobless & 33 & 7 & 40 & 8.1 & 1.7 & 9.8 \\
\hline House wife & 73 & 21 & 94 & 17.9 & 5.1 & 23.0 \\
\hline Inactive & 36 & 9 & 45 & 8.8 & 2.2 & 11.0 \\
\hline Student & 23 & 7 & 30 & 5.6 & 1.7 & 7.4 \\
\hline \multicolumn{7}{|l|}{ Insomnia } \\
\hline Present & 273 & 57 & 330 & 66.9 & 14.0 & 80.9 \\
\hline Absent & 58 & 20 & 78 & 14.2 & 4.9 & 19.1 \\
\hline \multicolumn{7}{|l|}{ Hypnotic drug use } \\
\hline No & 272 & 66 & 338 & 66.7 & 16.2 & 82.8 \\
\hline Yes & 59 & 11 & 70 & 14.5 & 2.7 & 17.2 \\
\hline \multicolumn{7}{|c|}{$\begin{array}{l}\text { Use of alternative means } \\
\text { to improve sleep }\end{array}$} \\
\hline No & 211 & 47 & 258 & 51.7 & 11.5 & 63.2 \\
\hline Yes & 120 & 30 & 150 & 29.4 & 7.4 & 36.8 \\
\hline
\end{tabular}

Legend: EDS, excessive daytime sleepiness. 
Table 2. Distribution of chi-square values applied to Excessive Daytime Sleepiness, in relation to sex, age, schooling, economic social status, marital status, employment, presence of insomnia, the use of hypnotic drugs and alternative means for better sleep.

\begin{tabular}{lccc}
\hline Variable & Chi-square & $\begin{array}{c}\text { Degree of } \\
\text { Freedom }\end{array}$ & $\mathrm{p}$ \\
\hline Sex & 2.40 & 1 & 0.1213 \\
Age & 2.38 & 5 & 0.7951 \\
Schooling & 3.31 & 4 & 0.5080 \\
Economic social & 1.04 & 3 & 0.7927 \\
Marital status & 0.44 & 3 & 0.9315 \\
Employment & 2.56 & 5 & 0.7674 \\
Insomnia & 2.89 & 1 & 0.0894 \\
Hypnotic drug use & 0.55 & 1 & 0.4581 \\
Alternative* & 0.17 & 1 & 0.6572 \\
\hline
\end{tabular}

Legend: *Use of alternative means to improve sleep.

Table 3. Distribution of chi-square values applied to Excessive Daytime Sleepiness in the male group, in relation to age, schooling, economic social status, marital status, employment, presence of insomnia, the use of hypnotic drugs and alternative means for better sleep.

\begin{tabular}{lccc}
\hline \multicolumn{4}{c}{ Males } \\
\hline Variable & Chi-square & $\begin{array}{c}\text { Degree of } \\
\text { Freedom }\end{array}$ & $\mathrm{p}$ \\
\hline Age & 4.76 & 5 & 0.4463 \\
Schooling & 7.79 & 4 & 0.0994 \\
Economic social & 2.52 & 3 & 0.4715 \\
Marital status & 1.35 & 3 & 0.7173 \\
Employment & 2.52 & 4 & 0.6406 \\
Insomnia & 7.89 & 1 & 0.0050 \\
Hypnotic drug use & 0.15 & 1 & 0.7028 \\
Alternative* & 1.09 & 1 & 0.2966 \\
\hline
\end{tabular}

Legend: *Use of alternative means to improve sleep.

EDS was analyzed according to sex, this correlation was significant $(p=0.0050)$ only in the male group. Two recent population based studies have shown the significant positive association between EDS and insomnia ${ }^{9,16}$. In Hublin et al. ${ }^{9}$ study, among persons with EDS, $20.7 \%$ of the women and $28.6 \%$ of the men presented insomnia. In the study by Ohayon et
Table 4. Distribution of chi-square values applied to Excessive Daytime Sleepiness in the female group, in relation to age, schooling,economic social status, marital status, employment, presence of insomnia, the use of hypnotic drugs and alternative means for better sleep.

\begin{tabular}{lccc}
\hline \multicolumn{4}{c}{ Females } \\
\hline Variable & Chi-square & $\begin{array}{c}\text { Degree of } \\
\text { Freedom }\end{array}$ & $\mathrm{p}$ \\
\hline Age & 3.64 & 5 & 0.6026 \\
Schooling & 1.85 & 4 & 0.7627 \\
Economic social & 2.28 & 3 & 0.5161 \\
Marital status & 2.38 & 3 & 0.4971 \\
Employment & 4.28 & 5 & 0.5093 \\
Insomnia & 0.02 & 1 & 0.8891 \\
Hypnotic drug use & 1.15 & 1 & 0.2837 \\
Alternative* & 0.13 & 1 & 0.7180 \\
\hline
\end{tabular}

Legend: *Use of alternative means to improve sleep.

al. ${ }^{16}$, the groups with severe and moderate EDS had higher prevalence of insomnia, respectively, $8.1 \%$ and $4.4 \%$, compared with the group without EDS in which only $1.4 \%$ presented insomnia.

The positive correlation between insomnia and EDS is still not clearly understood while small and special population studies do not confirm this correlation $^{30}$. Small sample studies utilizing other methods of EDS measurement, including the Stanford Sleepiness Scale, and the Multiple Sleep Latency Test ${ }^{30}$ did not show correlation between insomnia and EDS. The pupilometry studies, another biological marker of EDS, results have not been consistent enough to define the relation between EDS and insomnia ${ }^{30,31}$.

\section{CONCLUSION}

The high prevalence of EDS (18.9\%) in Campo Grande city was similar to that observed in most other recent general population studies in Europe, North America and South America. There was significant positive correlation between EDS and insomnia (only in the male group). We may suppose that sleep reduction and fragmentation leads to EDS on the next day; and, as it is chronically maintained, to impairment of daytime performance.

\section{REFERENCES}

1. Johnson EO, Breslau N, Roehrs T, Chase G, Drake C, Roth T. Epworth and daytime sleepiness scales: psychometric comparison in a community-based sample. Sleep 2001;24:108-109. 
2. Ohayon MM, Vecchierini MF, Lubin S. Excessive daytime sleepiness and insomnia in an elderly population. Sleep 2001;24:345-346.

3. Stal V, Billaud M, Laaban JP, Lubin S, et al. Evaluation of the French version of the Epworth Sleepiness Scale in a group of 274 subjects with hypersomnia. Sleep 2001;24:414-415.

4. Johnson EO, Breslau N, Roth T, Roehrs T, Rosenthal L. Psychometric evaluation of daytime sleepiness and nocturnal sleep onset scales in a representative community sample. Biol Psychiatry 1999;45:764-770.

5. Johns M, Hocking B. Excessive daytime sleepiness and sleep habits of Australian workers. Sleep 1997;20:844-849.

6. Izquierdo-Vicario Y, Ramos-Platón MJ, Conesa-Peraleja D, LozanoParra AB. Epworth Sleepiness Scale in a sample of the Spanish population. Sleep 1997;20:676-677.

7. Whitney CW, Enright PL, Newman AAB, Bonekat W, Fole D, Quan SF. Correlates of daytime sleepiness in 4578 elderly persons: the Cardiovascular Health Study. Sleep 1998;21:27-36.

8. Hara C. Projeto Bambuí: estudo de base populacional de prevalência e fatores associados a sonolência excessiva diurna. Dissertação de Mestrado, Universidade Federal de Minas Gerais. Belo Horizonte 2001.

9. Hublin C, Kaprio J, Partinen M, et al. Daytime sleepiness in an adult Finnish population. J Intern Med 1996;239:417-423.

10. Martikainen N, Urponen H, Partinen M, et al. Daytime sleepiness: a risk factor in community life. Acta Neurol Scand 1992;86:337-341.

11. Janson C, Gislason T, Backer W, et al. Daytime sleepiness, snoring and gastro-esophageal reflux amongst young adult in three European countries. J Intern Med 1995;237:177-195.

12. Téllez-Lopez A, Sánchez MEG, Torres FG et al. Hábitos y transtornos del dormir en residentes del area metropolitana de Monterrey. Salud Mental 1995;18:14-22.

13. Baldwin CM, Griffith KA, Nieto FJ, O'Connor GT, Wasleben J, Redline $\mathrm{S}$. The association of sleep-disordered breathing and sleep symptoms with quality of life in the Sleep Health Study. Sleep 2001;24:96-105.

14. Roth T, Roehrs TA. Etiologies and sequelae of excessive daytime sleepiness. Clin Ther 1996;18:526-535.

15. Guilleminault C, Brooks SN. Excessive daytime sleepiness: a challenge for the practicing neurologist. Brain 2001;124:1482-1491.

16. Ohayon MM, Caulet M, Philip P, et al. How sleep and mental disorders are related to complaints of daytime sleepiness. Arch Intern Med 1997;157:2645-2652.
17. Roberts RE, Shema SJ, Kaplan GA, et al. Sleep complaints and depression in an aging cohort: a prospective perspective. Am J Psychiatry 2000;157:81-88.

18. Maycock G. Sleepiness and driving: the experience of UK car drivers. Accid Anal Prev 1997;29:453-462.

19. Philip P, Taillard J, Niedhammer I, Guilleminault C, Bioulac B. Is there a link between subjective daytime somnolence and sickness absenteeism? A study in a working population. J Sleep Res 2001;10:111-115.

20. Guilleminault C, Stoohs R, Clerk A. Daytime somnolence therapeutic approaches. Neurophysiol Clin 1993;23:23-33.

21. Haraldson PO, Carenfelt C, Tingvall C. Sleep apnea syndrome symptoms and automobile driving in a general population. J Clin Epidemiol 1992;45:821-825.

22. Hays JC, Blazer DG, Foley DJ. Risk of napping: excessive daytime sleepiness and mortality in an older community population. J Am Geriatr Soc 1996;44:693-698.

23. Newman AB, Spiekerman CF, Enright P, et al. Daytime sleepiness predicts mortality and cardiovascular disease in older adults. J Am Geriatr Soc 2000;48:1115-1123.

24. Fundação Instituto Brasileiro de Geografia e Estatística (IBGE). Contagem populacional 1996. Rio de Janeiro: IBGE, 1996.

25. Johns MW. A new method for measuring daytime sleepiness: the Epworth Sleepiness Scale. Sleep 1991;14:540-545.

26. Giglio SB. Estudo da ocorrência das queixas de insônia, de sonolência excessiva diurna e das relativas às parassônias na população adulta da cidade de São Paulo. Tese de Doutorado, Escola Paulista de Medicina, São Paulo, 1988.

27. American Sleep Disorders Association. International classification of sleep disorders, revised. Diagnostic and coding manual. Rochester: American Sleep Disorders Association, 1997.

28. Reimão R. Escala de Sonolência Epworth: técnica, indicação e interpretação. Neurobiologia (Recife) 1998;60:17-24.

29. Associação Americana de Psiquiatria. Manual diagnóstico e estatístico de transtornos mentais. DSM-IV, 4 ed. Porto Alegre: Artes Médicas, 1995.

30. Lickstein KL, Wilson NM, Noe SL, et al. Daytime sleepiness in insomnia: behavioral, biological and subjective indices. Sleep 1994;17:694-702.

31. Lickstein KL, Johnson RS, Sengupta S, et al. Are insomniacs sleepy during the day? A pupillometric assessment. Behav Res Ther 1992;30:283-292. 